\title{
Екологічна безпека сучасних систем захисту рослин
}

\author{
В.В. Безпалько ${ }^{1}$, Л.В. Жукова ${ }^{2}$ \\ ${ }^{1}$ Харківський національний технічний університет сільського господарства \\ імені Петра Василенка (м. Харків, Україна) \\ 2 Харківський національний аграрний університет \\ ім. В.В. Докучаєва (м. Харків, Україна) \\ email: ${ }^{1}$ bezpalkovalentyna@gmail.com
}

\begin{abstract}
В статті проаналізовано існуючі різноманітні засоби захисту рослин для регулювання чисельності шкодочинних організмів. Вони $є$ невід'ємним прийомом сучасних технологій вирощування сільськогосподарських культур. Для прийняття оптимального рішення по застосуванню будь якого методу захисту рослин необхідно розглядати агроекосистему в цілому. За останні два десятиліття суттєві зміни погодних умов, розподіл їх по сезонам року, вплинули не тільки на якість і екологічну чистоту продукції, але і на збереження ресурсів при агроекологічних підходах ведення сільського господарства. Наведено переваги та недоліки застосування хімічного захисту рослин, який на сьогодні домінує в системі захисту рослин. Розкрито потенціал біологічного методу захисту рослин, який $є$ альтернативою хімічному при вирощуванні сільськогосподарських культур. Останнім часом цьому методу приділяють усе більшу увагу в зв'язку з тим, що широке застосування хімічного методу становить небезпеку для здоров'я людей і порушує екологічні процеси в природі, згубно впливає на корисну мікрофрлору. Урахування екологічної шкоди, економічної доцільності та екологічної безпеки заходів хімічного захисту має бути обов'язковою. Технічна, господарська та економічна ефективність застосування пестицидів дають можливість оцінити результати захисту рослин. Екологічні проблеми, що виникають при застосуванні пестицидів спонукають до пошуку нових методів регулювання чисельності шкідливих організмів. Нова концепція інтегрованого захисту рослин - це управління динамікою популяцій шкідливих і корисних організмів на основі фрітосанітарних прогнозів різної завчасності та цілеспрямованого застосування сучасних методів і засобів захисту рослин з урахуванням охорони навколишнього середовища та використання економічних порогів шкодочинності. Основним принципом природокористування має бути еколого-економічний принцип.
\end{abstract}

Ключові слова: засоби захисту, шкодочинні організми, збудники хвороб, фрітонциди, пестициди.

Аналіз літературних джерел. Втрати рослинної продукції від шкідливих організмів в середньому складають 30 \%. Стабільність землеробства, рівень урожайності значною мірою залежать від фітосанітарного стану посівів. Сучасні системи захисту рослин мають бути спрямовані на підвищення стійкості культур та створення умов, що обмежують розмноження й шкодочинність збудників хвороб, бур'янів та шкідників. Тобто акцент робиться на природоохоронному напрямку та зональних особливостях у сфері регулювання чисельності шкідливих організмів.

Хімічний метод, або застосування пестицидів, започатковано понад 250 років тому, коли в середині XYIII століття почали протруювати насіння злакових культур ртутними і миш'яковими препаратами. У 70-х роках минулого століття хімічний метод зазнав критики вчених і практиків, після чого почалося його вдосконалення [1].

Накопичення пестицидів в клітинах рослин i тварин приводить до порушення процесів обміну і концентруються живими організмами і порушу- ють рівновагу в природних екосистемах. Накопичення пестицидів в продуктах харчування зберігається тривалий час в різних екологічних ланцюгах живлення [2].

За останні $30-40$ років темпи приросту витрат на захист у 8-10 разів перевищували темпи збільшення врожайності основних культур. Системи захисту рослин були спрямовані на інтенсивне використання хімічних засобів без відповідного обґрунтування в екологічному відношенні. В наш час все більше визнання отримує ідея переходу до управління екосистеми [3]. А тому, вибір оптимального методу захисту рослин потребує конкретної характеристики екологічної ситуації. Агроекологічні підходи до ведення сільського господарства не потребують великих капіталовкладень, але вимагають переосмислення екологічної структури біоценозу [7].

Для пестицидів, які застосовують у сільському господарстві для контролю хвороб, бур'янів та шкідників культур, властивий побічний вплив на ґрунтові мікроорганізми. Пестициди накопичу- 
ючись у ґрунті, можуть інгібувати або стимулювати розвиток корисної мікрофрлори, а також патогенів, які не мають практичного значення у звичайних умовах. Гербіциди є постійно діючим екологічним фактором впливу на життєдіяльність ґрунтових мікроорганізмів. Хімічні обробки здебільшого призводять до загибелі чутливих до певних препаратів видів мікроорганізмів, активації стійких мутантів і видів, які використовують гербіцид як енергетичний матеріал. Як наслідок - порушення стану рівноваги ґрунтової екосистеми і умов самоочищення ґрунту, звуження спектра мікробіологічної активності [10]. Але бідою сучасного сільськогосподарського виробництва є й те, що на ринок України потрапляє величезна кількість підробної продукції пестицидів [1].

Навіть за високої культури землеробства та дотримання всіх вимог технологій вирощування сільськогосподарських культур у кожному господарстві повинні бути готовими до застосування інтегрованої системи захисту. Агротехнічні й біологічні як базові, я хімічні - доповнюючі [3, 4].

Постановка проблеми. Однією із провідних проблем сьогодення розглянути екологічні аспекти захисту рослин, з метою зменшення пестицидного навантаження на ґрунт та впровадження альтернативних методів регулювання чисельності шкідливих організмів.

Викладення основного матеріалу. Підвищення врожайності сільськогосподарських культур в умовах сучасного господарювання неможливе без надійного захисту рослин від шкідливих організмів. Причиною недобору близько третини врожаю нині $є$ несприятливі умови розвитку культурних рослин, а також вплив шкідників, хвороб і бур'янів.

Вони не тільки знижують рівень урожайності сільськогосподарських культур, але й значною мірою погіршують якість продукції та призводять до значного зростання її собівартості.

Регулювання чисельності шкодочинних організмів можливе через профрілактичні (запобіжні ) та винищувальні заходи.

Інтегровані системи включають в себе такі методи захисту рослин: організаційні, фрітоценотичні, імунологічні, агротехнічні, біологічні, фрізичні та хімічні.

Важливе місце у захисті рослин відводиться впровадженню стійких до хвороб та шкідників сортів та гібридів культурних рослин, що мають високу конкурентну здатність до бур'янів; використанню агротехніки у зменшенні запасів насіння бур'янів та резерваціях патогенів на полях; підвищенню стійкості рослин до несприятливих погодних умов по фазам вегетації, застосуванню біологічних і хімічних засобів захисту рослин із суворим дотриманням правил охорони навколишнього середовища; здійсненню карантинних заходів по недопущенню і локалізації поширення карантинних об'єктів.
В системі захисту рослин сільськогосподарського призначення обов'язково потрібно враховувати довгостроковий і короткостроковий прогнози, а також динаміку розвитку хвороб, появи шкідників та бур'янів, щоб забезпечити більш ефрективні та економічно вигідні наслідки в агрономічній роботі.

Значну роль у контролюванні чисельності шкідників, бур'янів та збудників хвороб відіграють сівозміни. Насиченість їх однією культурою впливає на особливості поширення та розмноження шкодочинних організмів. При дотриманні термінів повернення культур на попереднє місце їх вирощування та забезпеченні кращими попередниками можливо пригнічувати патогенну мікрофрлору, робити відсутньою кормову базу для шкідників і контролювати бур'яни.

Захисна функція агротехнічних заходів виявляється у запобіганні інтенсивному розмноженню шкідливих організмів, а також реалізації сортових властивостей стійкості рослин та конкурентної спроможності їх у використанні поживних елементів і вологи. Крім цього вони забезпечують формування передумов високої господарської, економічної та екологічної ефективності інших заходів захисту. Обробіток ґрунту виконує важливу роль в управлінні динамікою розвитку шкідливих організмів у агроценозах. Деякі заходи мають профрілактичний характер, але окремими агроприйомами можна безпосередньо знищувати шкідників.

Використання фрітонцидних рослин - ще один перспективний напрямок регулювання шкідливих об'єктів. Фітонциди - як біологічно активні речовини з антимікробною дією, виробляються рослинами. Фітонцидні рослини можуть відлякувати шкідників, складати конкуренцію бур'янам та згубно діяти на патогени.

Фізичні методи захисту рослин нині використовуються на невеликих площах (в плодових насадженнях, в закритому ґрунті, або на присадибних ділянках). Фізичний метод включає використання електромагнітного поля, а також (МХП $\mathrm{HB} 4)$ надзвичайно високих частот як окремо так i в поєднанні з біопрепаратами [13].

Обробка насіння МХП НВЧ у визначених режимах опромінення окремо або з додатковою обробкою регуляторами росту Mapc EL (пшениці) i Радостим або Альбіт (ячмінь) зумовлює зниження рівня поширеності та розвитку кореневих гнилей в посівах цих культур [13].

3 метою підвищення екологічної безпечності існуючих технологій вирощування та підвищення урожайності пшениці озимої та ячменю ярого (зокрема в системах органічного землеробства) передпосівне протруєння насіння хімічними протруйниками слід замінити передпосівним опроміненням насіння мікрохвильовим полем надзвичайно високих частот (МХП НВЧ) в наступних режимах і способах залежно від культури $[14,15]$. 
При перевищенні шкідливими об'єктами рівня економічного порогу шкодочинності рекомендується застосовувати пестициди. Так як хімічний метод домінує в інтегрованих системах захисту рослин, то необхідно приділяти більше уваги його безпечному застосуванню, звертаючи особливу увагу на його післядію і вплив на об'єкти навколишнього середовища.

Асортимент пестицидів, їх різні форми та способи застосування за неповних три століття використання хімічного методу дуже змінилися. Сучасні препарати містять дві-три діючі речовини, що розширює та продовжує спектр їх дії. Слід відмітити, що протягом останнього десятиліття значно зросло використання протруювачів насіння та посадкового матеріалу, а також регуляторів росту рослин. Ці препарати в переважній більшості характеризується тим, що підвищують імунітет культурних рослин.

Сучасні способи хімічного контролювання шкідливих організмів крім позитивних мають ще й негативні сторони пливу на довкілля. Загальновідомо, що від 25 до 75 \% норми витрати пестицидів під час обприскування потрапляють не за призначенням, а лише забруднюють навколишнє середовище.

Локальні обробки пестицидами є високоефективними, тому що дозволяють зменшити чисельність шкодочинних організмів при мінімальних витратах пестицидів. До них відносяться: обробка крайових смуг посівів, стрічкове та гніздове внесення пестицидів, спрямоване обприскування, обробка куртин та окремих особин культурних рослин або шкодочинних організмів.

Альтернативним до хімічного $є$ біологічний метод контролювання чисельності шкодочинних організмів. Його особливостями є вузька специфрічність, нешкідливість для людей та тварин, відсутність негативного впливу на довкілля.

Біологічний метод ґрунтується на використанні живих організмів або продуктів їхньої життєдіяльності 3 метою зменшення чисельності та шкодочинності шкідливих організмів. Він полягає у використанні паразитичних або хижих тварин та мікроорганізмів - збудників хвороб і комах.

Для біологічного захисту рослин від трипсів, використовується хижий клоп Neoseiuhts cucumeris, використовуються також і інші ентомофраги, наприклад, хижий клоп Amblyseius swirskii i Orius insidiosus. Важливе місце в раціоні Neoseiuhts cucumeris займає пилок. Було встановлено, що пилок може бути для нього альтернативним або додатковим джерелом їжі. Наявність пилку прискорює розвиток і збільшує плодючість хижака. Neoseiuhts cucumeris використовується для контролю кількості трипсів на різних культурах. Цей хижак воліє годуватися на молодих стадіях розвитку трипсів, але він також може харчуватися павутинним кліщем на різних етапах його розвитку та дрібними комахами. Хижий клоп також є хижаком для павутинного кліща на суниці, і там, де $є$ симптоми цього шкідника, ви повинні ввести великі кількості цього хижака. Він може бути застосований у формі маленьких пакетиків, в кожному з яких знаходиться близько 1000 дорослих клопів і висівки в якості носія (або у вільному об'ємі (змішаний з висівками) [12].

Фітосейулюс - Phytoseiulus persimilis Ath.Henr. (родина фітосейїди Phytoseidae, ряд паразитоїдні кліщі Parasitiformes). Це спеціалізований хижак звичайного павутинного кліща

За харчовою спеціалізацією фітосейулюс $€$ типовим олігофагом. Він живиться представниками родини павутинних кліщів (звичайний, садовий павутинний, глодовий та ін.). Фітосейулюс $€$ агресивним хижаком, який значною мірою пристосований до проживання в дуже «запавутинених» колоніях тетраніхових кліщів. Канібалізм у фітосейулюса майже не виражений. Життєвий цикл фітосейулюса проходить на зелених частинах рослин, заражених павутинними кліщами.

Біологічні параметри фітосейулюса, за інших умов (температура, вологість), значною мірою залежить від виду кормової рослини, на якій відбувається живлення павутинного кліща, наприклад на сої, плодючість у середньому становить 69,1 яйця, троянді 59,6, хризантемі 45,1 і на гвоздиці 32,5 яйця. 3 практичного погляду найбільшу цікавість представляє темпи росту популяції хижака на різних рослинах господарях.

Установлено, що у разі живлення павутинним кліщем на сої популяція фрітосейулюса зростає на 10-й день у 28 разів. Будучи спеціалізованим хижаком павутинних кліщів, фрітосейулюс не може тривалий час зберігатися на рослинах, вільних від його жертви, і скоро (через 3-4 доби) гине. У промислових умовах, коли виникають нові вогнища павутинного кліща, необхідно весь час розводити фітосейулюса в масовій кількості протягом всього вегетаційного періоду.

Останнім часом за кордоном набуло поширення використання мікогербіцидів препаратів, що містять у своєму складі спори фрітопатогенних грибів.

Основні напрямки використання біологічного методу:

- збереження та підвищення ефективності природних ресурсів ентомофрагів, збагачення агроценозів корисними організмами, використання патогенних мікроорганізмів та створення на їх базі біопрепаратів;

- біологічний захист рослин ґрунтується на використанні таких взаємовідносин між організмами, як антагонізм, конкуренція, гіперпаразитизм.

Біологічні прийоми захисту перспективні, як високоефективні та безпечні для теплокровних тварин[6].
ISSN 2311-1828

http://enm.khntusg.com.ua
Інженерія природокористування, 2020, №4(18), с. 133 - 138

Engineering of nature management, 2020, \#4(18), p. 133 - 138 
За даними О.Д. Козаренко (2013 р.) застосування гумітів у вирощуванні сільськогосподарської продукції дає змогу знизити хімічне навантаження на агроценоз шляхом зменшення норм фунгіцидів на 20-25 \% і норми внесення добрив на 20-30 \% без втрати врожайності. На оброблених посівах зростають якісні показники врожаю: збільшується вміст сухих речовин, білків, вітамінів, жирів залежно від культури та зменшується вміст нітратів, залишків засобів захисту рослин та важких металів. В центрі уваги - екологічне обґрунтування інтегрованих систем захисту посівів від шкідливих організмів та економічно виправдане поєднання агротехнічних, хімічних, фітоценотичних, фрізичних, біологічних та інших заходів у посівах окремих культур [5].

На даний час основним принципом природокористування має бути еколого-економічний принцип, який передбачає одержання максимального прибутку при мінімальних витратах та незначних впливах на навколишнє середовище [8, 9].

Ще одним перспективним шляхом екологізації захисту рослин є обмеження резистентності до пестицидів популяцій шкідливих організмів. Екологічно обґрунтована система захисту культурних рослин від шкідливих організмів становить досить складний технологічний процес, тому здійснюється вона послідовним проведенням комплексу заходів. [5].

Висновки. Таким чином, з метою вдосконалення інтегрованої системи захисту рослин та ії екологічної орієнтації необхідно оптимізувати технології вирощування культурних рослин із врахуванням ролі строків проведення робіт, норми висіву насіння, ширини міжряддя, глибини посіву, а також збільшити вплив системи удобрення культур на розвиток шкодочинних організмів, а також системи меліоративних заходів в обмеженні чисельності шкідників, бур'янів та збудників хвороб. Обов'язковим $€$ урахування екологічної шкоди, економічної доцільності та екологічної безпеки заходів хімічного захисту та розвиток технічної, господарської та економічної ефективності їх. Вирішення екологічних проблем, що виникають при застосуванні пестицидів та соціальна безпека заходів захисту рослин, оптимізація використання апаратури та засобів механізації захисту рослин.

\section{Література:}

1. Бабаянц О. Українській ниві - лише якісні 33Р. Пропозиція. 2012, № 9. С. 64-65.

2. Білик М.О. Біологоічний захист рослин. Харків: Майдан, 2009. 424 с.

3. Кулєшов А.В., Білик М.О. Фітосанітарний моніторинг і прогноз. Харків: Еспада. 2008. 512 с.

4. Лисенко А. Інтегрована система захисту від бур'янів. Пропозиція. 1998. №11. С. 30-31.
5. Козаренко Д.О. Застосування гумітів - перспективний метод зменшення хімічного навантаження на агроценози. Карантин і захист рослин.

6. Марков І. Біологічний захист рослин від хвороб. Пропозиція. 2004, №6. С. 82-87.

7. Мудрак О.В. Екологія. Вінниця, 2006. 598с.

8. Окрушко C.Є. Обґрунтування переходу до органічного землеробства у Вінницькій області. Органічне виробництво і продовольча безпека. Житомир, 2015. С. 523-526.

9. Окрушко С.Є. Екологічні аспекти захисту рослин. Матеріали Міжнародної науково-практичної конференції «Екологічні, економічні та соціальні проблеми розвитку аграрної сфери в умовах глобалізації». Харків, 2015. С. 205-208.

10. Старчоус І. Застосування гербіцидів : очікуваний ефект та побічний вплив. Пропозиція. 2014. №1. С. 100-105.

11. Трибель С.О., Стригун О.О., Гаманова О.М. Сучасний стан хімічного методу захисту рослин. Карантин і захист рослин. 2014. №1. С.1-4.

12. Стефрановська Т.Р., Кава Л.П., Підліснюк B.В., Томчак А.В.. Технологія вирощування і використання організмів у біологічному захисті рослин. Київ: «Агроосвіта» 2014, 254 с.

13. Безпалько В.В., Буряк Ю.І., Оздоровлення насіння мікрохвильовим полем надвисоких частот $з$ метою підвищення посівних якостей та врожайних властивостей пшениці озимої. Вісник центру наукового забезпечення АПВ Харківської області. Випуск № 15, Х. 2013. С.17-21.

14. Буряк Ю.І., Огурцов Ю.Є., Клименко І.І., Крупченко Л.В., Безпалько В.В., Солошенко О.В. Вплив рістрегулюючих препаратів і мікрохвильового опромінення посівного матеріалу на врожайність та посівні якості насіння ячменю ярого Збірник наукових праць: Основи біологічного рослинництва в сучасному землеробстві. Умань 2011. С. $303-309$.

15. Беспалько В.В., Буряк Ю.И. Влияние предпосевной обработки семян микроволновым полем в сочетании с регуляторами роста и биопрепаратом на посевные качества и урожайные свойства ячменя ярового. Всеросийский научно-производственный журнал. Зернобобовые и крупяные культуры. №3(12), 2014. Орел. С.133-138.

\section{References:}

1. Babaiants, O. (2012) 'Ukrainskii nyvi - lyshe yakisni ZZR', Propozytsiia, (9), pp. 64-65.

2. Bilyk, M., (2009). Biolohoichnyi zakhyst roslyn. Kharkiv: Maidan, p.424.

3. Kuljeshov, A. and Bilyk, M., 2008. Fitosanitarnyj monitoryngh i proghnoz. Kharkiv: Espada, p.512.

4. Lysenko, A., 1998. Integhrovana systema zakhystu vid bur'janiv. Propozycija, 11, pp.30-31.

5. Kozarenko, D., n.d. Zastosuvannja ghumitiv - perspektyvnyj metod zmenshennja khimichnogho navantazhennja na aghrocenozy. Karantyn i zakhyst roslyn,. 
6. Markov, I., 2004. Biologhichnyj zakhyst roslyn vid khvorob. Propozycija, 6, pp.82-87.

7. Mudrak, O., 2006. Ekologhija. Vinnycja, p.598.

8. Okrushko, S., 2015. Obgruntuvannja perekhodu do orghanichnogho zemlerobstva u Vinnycjkij oblasti. In: Orghanichne vyrobnyctvo i prodovoljcha bezpeka. Zhytomyr, pp.523-526.

9. Okrushko, S., 2015. Ekologhichni aspekty zakhystu roslyn. In: Materialy Mizhnarodnoji naukovo-praktychnoji konferenciji «Ekologhichni, ekonomichni ta socialjni problemy rozvytku aghrarnoji sfery $v$ umovakh ghlobalizaciji». Kharkiv, pp.205-208.

10. Starchous, I., 2014. Zastosuvannja gherbicydiv: ochikuvanyj efekt ta pobichnyj vplyv. Propozycija, 1, pp.100-105.

11. Trybelj, S., Stryghun, O. and Ghamanova, O., 2014. Suchasnyj stan khimichnogho metodu zakhystu roslyn. Karantyn i zakhyst roslyn, 1, pp.1-4.

12. Stefanovsjka, T., Kava, L., Pidlisnjuk, V. and Tomchak, A., 2014. Tekhnologhija vyroshhuvannja $i$ vykorystannja orghanizmiv u biologhichnomu zakhysti roslyn.. Kyjiv: Aghroosvita, p.254.
13. Bezpaljko, V. and Burjak, J., 2013. Ozdorovlennja nasinnja mikrokhvyljovym polem nadvysokykh chastot $z$ metoju pidvyshhennja posivnykh jakostej ta vrozhajnykh vlastyvostej pshenyci ozymoji. In: Visnyk centru naukovogho zabezpechennja APV Kharkivsjkoji oblasti, 15th ed. Kh., pp.17-21.

14. Burjak, J., Oghurcov, J., Klymenko, I., Krupchenko, L., Bezpaljko, V. and Soloshenko, O., 2011. Vplyv ristreghuljujuchykh preparativ i mikrokhvyljovogho oprominennja posivnogho materialu na vrozhajnistj ta posivni jakosti nasinnja jachmenju jarogho. In: Zbirnyk naukovykh pracj: Osnovy biologhichnogho roslynnyctva $v$ suchasnomu zemlerobstvi. Umanj, pp.303-309.

15. Bespaljko, V. and Burjak, J., 2014. Vlyjanye predposevnoj obrabotky semjan mykrovolnovыm polem $v$ sochetanyy $s$ reghuljatoramy rosta $y$ byopreparatom na posevnue kachestva y urozhajnыe svojstva jachmenja jarovogho. In: Vserosyjskyj nauchno-proyzvodstvennыj zhurnal. Zernobobovыe y krupjanыe kuljturы, 3rd ed. Orel, pp.133-138.

\section{Аннотация}

\section{Экологическая безопасность современных систем защиты растений}

\section{В.В. Беспалько, Л.В. Жукова}

В статье проанализированы существующие разнообразные средства защиты растений для регулирования численности вредоносных организмов. Они являются неотъемлемым приемом современных технологий выращивания сельскохозяйственных культур. Для принятия оптимального решения по применению какого-либо метода защиты растений необходимо рассматривать агроекосистему в целом. За последние два десятилетия существенные изменения погодных условий, распределение их по сезонам года, повлияли не только на качество и экологическую чистоту продукции, но и на сохранение ресурсов при агроэкологических подходах ведения сельского хозяйства. Приведены преимущества и недостатки применения химической защиты растений, которая сегодня доминирует в системе защиты растений. Раскрыт потенциал биологического метода защиты растений, который является альтернативой химическому при выращивании сельскохозяйственных культур. В последнее время этому методу уделяется все большее внимание в связи с тем, что широкое применение химического метода представляет опасность для здоровья людей и нарушает экологические процессы в природе, пагубно влияет на полезную микрофрлору. Учет экологического ущерба, экономической целесообразности и экологической безопасности при химической защите должно быть обязательным. Техническая, хозяйственная и экономическая эффрективность применения пестицидов дают возможность оценить результаты защиты растений. Экологические проблемы, возникающие при применении пестицидов побуждают к поиску новых методов регулирования численности вредных организмов. Новая концепция интегрированной защиты растений - это управление динамикой популяций вредных и полезных организмов на основе фитосанитарных прогнозов различной заблаговременности и целенаправленного применения современных методов и средств защиты растений с учетом охраны окружающей среды и использования экономических порогов вредоносности. Основным принципом природопользования должно быть эколого-экономический принцип.

Ключевые слова: средства защиты, вредоносные организмы, возбудители болезней, фритонциды, пестициды.

Інженерія природокористування, 2020, №4(18), с. 133 - 138

Engineering of nature management, 2020,\#4(18), p. 133 - 138 


\begin{abstract}

\section{Ecological safety of modern plant protection systems}

\section{V.V. Bezpal'ko, L.V. Zhukova}

The article analyzes the existing various plant protection products to regulate the number of pests. They are an integral part of modern technologies for growing crops. To make the optimal decision on the application of any method of plant protection, it is necessary to consider the agroecosystem as a whole. Over the past two decades, significant changes in weather conditions, their distribution by seasons, have affected not only the quality and environmental friendliness of products, but also the conservation of resources in agri-environmental approaches to agriculture. The advantages and disadvantages of the use of chemical plant protection, which currently dominates in the plant protection system, are presented. The potential of the biological method of plant protection, which is an alternative to chemical in the cultivation of crops, is revealed. Recently, this method is receiving more and more attention due to the fact that the widespread use of chemical methods is a danger to human health and disrupts environmental processes in nature, has a detrimental effect on the beneficial microflora. Consideration of the environmental damage, economic viability and environmental safety of chemical protection measures must be mandatory. Technical, economic and economic efficiency of pesticide application make it possible to evaluate the results of plant protection. Environmental problems arising from the use of pesticides encourage the search for new methods of regulating the number of pests. The new concept of integrated plant protection is the management of population dynamics of harmful and beneficial organisms on the basis of phytosanitary forecasts of different timeliness and purposeful application of modern methods and means of plant protection taking into account environmental protection and use of economic thresholds. The basic principle of nature management should be the ecological and economic principle.
\end{abstract}

Keywords: means of protection, harmful organisms, pathogens, phytoncides, pesticides.

\title{
Бібліографічне посилання/ Bibliography citation: Harvard
}

Bezpal'ko, V. V. and Zhukova, L. V. (2020) 'Ecological safety of modern plant protection systems', Engineering of nature management, (4(18), pp. $133-138$.

Подано до редакції / Received: 06.11.2020 